\title{
Cardiac Resynchronization Therapy: Lead Positioning and Technical Advances
}

\author{
Karl Mischke ${ }^{1}$ and Christian Knackstedt ${ }^{2}$ \\ ${ }^{1}$ Department of Cardiology, RWTH Aachen University Hospital, Aachen, \\ ${ }^{2}$ Department of Cardiology, Maastricht University Hospital, Maastricht, \\ ${ }^{1}$ Germany \\ 2The Netherlands
}

\section{Introduction}

Cardiac resynchronization therapy (CRT) is a therapeutic option for heart failure patients with a severely reduced left ventricular ejection fraction and left bundle branch block (Cleland et al., 2001). Ventricular resynchronization is achieved by biventricular pacing, usually via electrodes in the right ventricular apex and a left ventricular (LV) electrode positioned in a coronary vein.

About one third of implanted patients do not respond to CRT (Derval et al., 2010). In order to reduce the percentage of non-responders, several strategies have been developed. They include optimization of patient selection, device programming as well as LV lead location. In cardiomyopathy with left bundle branch block, the lateral wall is the site of latest activation and should be the optimal location for LV pacing. Therefore, standard implantation sites for LV leads are lateral or posterolateral branches of the coronary sinus. Congruent to these pathophysiological findings, Butter et al. demonstrated a superiority of lateral wall pacing versus anterior wall pacing in CRT (Butter et al., 2001). However, a more detailed look at optimal pacing locations might be required to increase the effect of CRT and decrease non-responder rates.

Different imaging modalities have been used to both identify optimal pacing sites as well as to plan LV lead implantation.

\section{Imaging for cardiac resynchronization therapy}

Imaging for CRT is focused on imaging of the coronary venous (CS) system for CS lead implantation and on imaging techniques to asses the left ventricular function for patient selection, choose the optimal lead position and to evaluate the effect of CRT.

Contrast angiography is commonly used for imaging of the coronary venous system. To evaluate ventricular function including dyssynchrony, transthoracic echocardiography is commonly applied as it is widely availably and inexpensive. A lot of efforts have been done to improve patient selection by echoardiographic screening and there are hundreds of papers published on echocardiographic evaluation of mechanical dyssynchrony, including the use of tissue Doppler imaging, speckle tracking, three-dimensional and contrast 
echocardiography. However, in the PROSPECT trial with almost 500 patients no single echocardiographic parameter could predict response with convincing sensitivity and specificity (Chung et al., 2008). Despite good results in single-center studies, echocardiography for assessment of dyssynchrony is limited by high intra- and interobserver variability, measurement errors and in some patients low image quality. Alternatives to echocardiography include magnetic resonance imaging, computed tomography and nuclear imaging. Magnetic resonance imaging has the benefit of high spatial resolution, high reproducibility and information on viability. A high scar burden and pacing over a posterolateral scar are associated with poor response to CRT (Bleeker et al., 2006, White et al., 2006). Whereas magnetic resonance imaging is the gold standard to assess myocardial viability, computed tomography also provides information on scar burden and localization as well as left ventricular function and dyssynchrony. However, data on dyssynchrony measured by computed tomography are limited and there are no published data for the prediction of CRT response. In addition, computed tomography is associated with radiation exposure. Nuclear imaging with single photon computed tomography and positron emission tomography is also associated with radiation exposure. Nuclear imaging provides information on scar burden and scar localization, ventricular function and dyssynchrony. However, a major disadvantage of nuclear imaging is the low spatial resoluation.

\subsection{Imaging of the coronary venous system}

Left ventricular leads are usually implanted in a lateral or posterolateral branch of the coronary sinus. Contrast venography is a standard procedure performed either before or during implantation to identify suitable target veins. Table 1 displays imaging modalities for the coronary venous system.

\begin{tabular}{|l|l|l|l|}
\hline & Advantages & Disadvantages & Clinical relevance \\
\hline $\begin{array}{l}\text { Retrograde contrast } \\
\text { CS angiography }\end{array}$ & $\begin{array}{l}\text { Good vessel visibility } \\
\text { Can be performed during } \\
\text { CRT implantation }\end{array}$ & invasive & $\begin{array}{l}\text { standard } \\
\text { procedure }\end{array}$ \\
\hline $\begin{array}{l}\text { Rotational CS } \\
\text { angiography }\end{array}$ & $\begin{array}{l}\text { 3D imaging } \\
\text { Can be performed during } \\
\text { CRT implantation }\end{array}$ & invasive & limited experience \\
\hline $\begin{array}{l}\text { Computed } \\
\text { tomography }\end{array}$ & Non-invasive & $\begin{array}{l}\text { radiation } \\
\text { exposure }\end{array}$ & limited experience \\
\hline MRI & $\begin{array}{l}\text { Non-invasive } \\
\text { No radiation exposure }\end{array}$ & $\begin{array}{l}\text { lower spatial } \\
\text { resolution }\end{array}$ & limited experience \\
\hline $\begin{array}{l}\text { Venous phase CS } \\
\text { angiography }\end{array}$ & $\begin{array}{l}\text { Can be performed during } \\
\text { standard coronary } \\
\text { angiography }\end{array}$ & $\begin{array}{l}\text { lower vessel } \\
\text { visibility }\end{array}$ & limited experience \\
\hline
\end{tabular}

Table 1. Imaging modalities for the coronary venous system

Because a lot of patients with heart failure undergo a coronary angiogram, we compared retrograde occlusion venography with venous phase imaging of the coronary sinus in 24 patients (Mischke et al., 2007). 


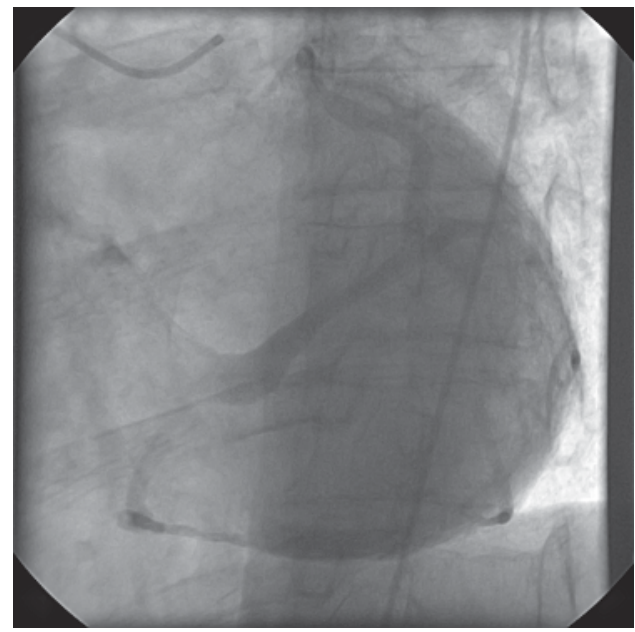

Fig. 1. Venous phase coronary sinus angiography (left anterior oblique projection).

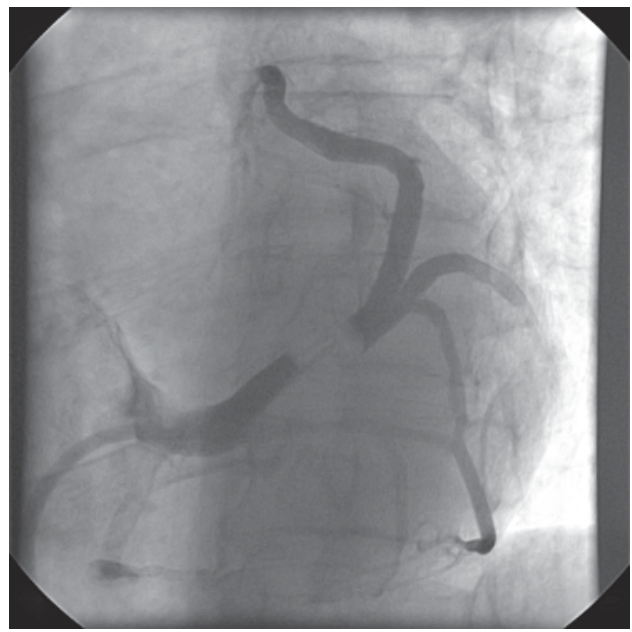

Fig. 2. Retrograde coronary sinus angiography (left anterior oblique projection).

Suitable target vessels for LV lead implantation were identified in all patients by both imaging modalities. Although visibility was superior in retrograde venography than in venous phase imaging, this technique might be an alternative to retrograde venography in patients undergoing a coronary angiogram. Venous phase angiography is time-saving and easy to perform. Figures 1 and 2 display a venous phase coronary sinus angiography and a retrograde occlusion venography.

Some of the standard C-arms used for fluoroscopy allow rotational angiography with a 3D image. In an animal model we compared rotational coronary sinus angiography to ECGgated enhanced cardiac dual source computed tomography (Knackstedt et al., 2008a). We found no significant difference between these imaging modalities with respect to vessel 
diameters or vessel visibility. In contrast to computed tomography, rotational angiography images can be obtained within seconds in the catheter lab without a time lag between cardiac imaging and procedure. In addition, estimated radiation exposure and the amount of contrast medium were lower in rotational coronary sinus angiography.

We compared retrograde coronary sinus angiography with multi-slice computed tomography for visualization of the coronary venous system in 20 patients with congestive heart failure (Knackstedt et al., 2008b). Vessel visualization was better using retrograde coronary sinus angiography except for the middle cardiac vein and small veins, which were better seen with computed tomography. There was a trend that computed tomography detected more vessels. Overall, retrograde coronary sinus angiography offered a better display of target vessels commonly used for LV lead implantation.

Imaging of the coronary sinus via cardiac computed tomography correlates well with direct coronary sinus venography (Van de Verie et al., 2006). Imaging of the coronary venous anatomy by computed tomography is non-invasive and can help to plan coronary sinus lead implantation especially in patients with angulated coronary veins and in patients in whom a left marginal vein or a posterior vein is absent. It also provides information on the localization of the left phrenic nerve in relation to the target vein. However, it is associated with radiation and contrast agent exposure.

Magnetic resonance imaging of the coronary venous anatomy allows adequate assessment of localization, size and angulations of the veins (Ma et al., 2010; Nezafat et al., 2007). However, spatial resolution is inferior to computed tomography and magnetic resonance imaging cannot routinely be performed in patients with cardiac implants, e.g. patients scheduled for an upgrade from an implantable cardioverter defibrillator (ICD) to a CRT device.

\subsection{Magnetic resonance imaging in CRT patients}

Implanted devices like pacemakers and ICDs generally pose a contraindication to magnetic resonance imaging. However, magnetic resonance imaging might be performed with only small risks for the patient and device. In order to reduce the risks, careful patient selection, constant monitoring, specific absorption rate management and careful device programming before the scan have been used in the past. In a recent study Wilkoff et al. evaluated the safety of a pacemaker especially designed for safe magnetic resonance imaging (Wilkoff et al., 2011). Several modifications were used to improve the safety of magnetic resonance imaging, including modification of the leads to reduce lead tip heating, reduction of the amount of ferromagnetic materials, replacement of the reed switch by a Hall sensor, whose behaviour in a static magnetic field is predictable. In this prospective randomized study magnetic resonance imaging with a $1.5 \mathrm{~T}$ scanner could be performed without adverse events.

\section{Left ventricular lead implantation}

Cardiac resynchronization requires left ventricular pacing. The standard approach for left ventricular lead implantation is a transvenous implantation into a lateral or posterolateral tributary of the coronary sinus. Although dedicated instruments allow successful LV lead implantation in most patients, failure rates of $5-17 \%$ have been reported (Abraham et al., 2002; Al-Khadra et al., 2005; Purerfellner et al., 2000). In these patients, LV leads are usually implanted onto the LV epicardium through thoracotomy or thoracoscopy. In addition, there are several alternatives to standard LV lead implantation techniques, including endocardial LV lead implantation, LV lead implantation assisted by magnetic navigation and video- 
assisted pericardioscopic epicardial LV lead implantation. As the access to LV regions is limited by the anatomy of the venous coronary system in standard procedures with transvenous CS lead implantation, some strategies aim at improved access to LV regions:

- Epicardial stimulation

- Endocardial LV stimulation

- Magnetic navigation for CS lead implantation

- $\quad$ Microcatheter LV stimulation

Table 2 lists advantages und risks of LV lead implantation techniques.

\begin{tabular}{|l|l|l|l|}
\hline $\begin{array}{l}\text { Standard } \\
\text { transvenous } \\
\text { implantation into } \\
\text { CS tributary }\end{array}$ & $\begin{array}{l}\text { Low } \\
\text { periprocedural risk }\end{array}$ & $\begin{array}{l}\text { Disadvantages } \\
\text { LV regions } \\
\text { Risk of dislocation } \\
\text { Failure in 5-17\% }\end{array}$ & $\begin{array}{l}\text { Clinical relevance } \\
\text { implantation } \\
\text { procedure }\end{array}$ \\
\hline $\begin{array}{l}\text { Epicardial } \\
\text { implantation via } \\
\text { thoracotomy or } \\
\text { thoracoscopy }\end{array}$ & $\begin{array}{l}\text { Access to all LV } \\
\text { regions }\end{array}$ & Surgical risks & $\begin{array}{l}\text { First-line alternative } \\
\text { to transvenous LV } \\
\text { lead implantatoin }\end{array}$ \\
\hline $\begin{array}{l}\text { Endocardial LV } \\
\text { lead implantation }\end{array}$ & $\begin{array}{l}\text { Access to all LV } \\
\text { regions } \\
\text { Fast impulse } \\
\text { propagation }\end{array}$ & $\begin{array}{l}\text { Risk of } \\
\text { thromboembolism }\end{array}$ & $\begin{array}{l}\text { limited experience } \\
\text { with patients }\end{array}$ \\
\hline $\begin{array}{l}\text { Magnetically } \\
\text { navigated CS lead } \\
\text { implantation }\end{array}$ & $\begin{array}{l}\text { Possibly improved } \\
\text { access to target } \\
\text { vessels }\end{array}$ & $\begin{array}{l}\text { Experimental/limited } \\
\text { experience with } \\
\text { patients }\end{array}$ \\
\hline $\begin{array}{l}\text { Video-assisted } \\
\text { pericardioscopic } \\
\text { epicardial } \\
\text { implantation }\end{array}$ & $\begin{array}{l}\text { Access to all LV } \\
\text { regions }\end{array}$ & & Experimental \\
\hline
\end{tabular}

Table 2. LV lead implantation techniques

\subsection{Alternatives to right ventricular pacing}

Whereas right ventricular apical pacing is the standard for patients requiring a pacemaker, this mode of stimulation is associated with electromechanical dyssynchrony and may contribute to worsening of the cardiac function (Tantengco et al., 2001). Because of the detrimental effects of right ventricular apical pacing several strategies have been suggested to avoid or reduce right ventricular apical pacing, including biventricular pacing either by de novo implantation of a CRT device or by upgrading an existing pacemaker, changes in programming to reduce the percentage of right ventricular pacing and alternative pacing sites. Careful patient selection and minimal ventricular pacing algorithms can substantially reduce the amount of right ventricular pacing and have been implemented into clinical practice (Tops et al., 2009). Several studies have demonstrated a hemodynamic and symptomatic benefit of upgrading right ventricular apical pacing to CRT as well as CRT in patient with indications for permanent pacing (Tops et al, 2009). However, so far it remains uncertain whether this will translate into a prognostic benefit. Alternative pacing sites have been suggested to avoid right ventricular apical pacing, including pacing the right 
ventricular outflow tract, septal pacing and direct His bundle pacing. A meta-analysis by de Cock (de Cock et al., 2003) showed a favorable hemodynamic effect, and a study by Venerio (Vanerio et al., 2008) demonstrated an improved survival in patients with right ventricular outflow tract pacing as compared to right ventricular apical pacing. However, most studies include rather small numbers of patients and are of short follow up, so more data are needed to evaluate the relevance of right ventricular outflow tract pacing for clinical routine. Septal pacing has been shown to decrease ventricular dyssynchrony compared to right ventricular apical pacing (Yu et al., 2007) but there was no difference in left ventricular ejection fraction in a prospective study by Kypta (Kypta et al., 2008). Direct His-bundle pacing or para-Hisian pacing allows a more physiological impulse propagation than right ventricular apical pacing but is associated with difficulties in lead positioning and concerns about pacing thresholds (Tops et al., 2009).

Henz (Henz et al., 2009) demonstrated in a small animal study the feasibility of atrioventricular septal synchronous pacing with intramyocardial leads implanted deep within the atrioventricular septum; further animal studies are needed to evaluate this approach.

\subsection{Optimized CS lead implantation}

Already a decade ago Butter et al. demonstrated a hemodynamic superiority of pacing from a lateral vein compared to an anterior vein for CRT (Butter et al., 2001). The distance between stimulation site and the region of latest contraction may be crucial for hemodynamic benefit of CRT (Ypenburg et al., 2008). This is in line with findings from animal studies (Helm et al., 2007) and studies using echocardiographic parameters in patients (Becker et al., 2007a and 2007b).

We used computed tomography and MRI imaging prior to LV lead implantation in 20 patients with congestive heart failure (Knackstedt et al., 2010a). Computed tomography was used for imaging of the coronary venous system and MRI to detect the region of latest contraction. Computed tomography and MRI images were then over-imposed to determine a coronary side branch suitable for lead implantation that is closest to the region of latest contraction. There was a trend towards a shorter distance between the LV lead and the region of latest contraction in patients classified as responders.

Another approach is the use of myocardial deformation analysis assessed by circumferential strain analysis during echocardiography to determine the optimal site for CS lead implantation. In a study with 56 patients optimal LV lead position was defined as a lead position close to the segment with latest systolic strain prior to CRT (Becker et al., 2010). During follow up, patients with leads implanted in an "optimal position" experienced a significantly higher increase in left ventricular ejection fraction than patients with leads implanted at other sites.

In a smaller study Ducket et al. performed computed tomography and MRI to acquire 3D whole heart images. After segmentation, 3D anatomical models were overlaid over live fluoroscopy to guide LV lead implantation (Ducket et al., 2010).

\subsection{Endocardial LV lead implantation}

Endocardial lead implantation is associated with a high risk of systemic thromboembolism (van Gelder et al., 2000). However, endocardial LV lead implantation has several (potential) advantages to CS and epicardial LV leads: it allows access to all LV regions, endocardial ventricular layers offer faster impulse propagation than epicardial leyers and endocardial stimulation might result in improved hemodynamics. Van Deursen demonstrated in an 
acute canine model a superior electrical resynchronization as well as $+\mathrm{dP} / \mathrm{dT}(\max )$ when endocardial biventricular stimulation was used instead of epicardial stimulation. In addition, whereas epicardial stimulation resulted in a transmural dispersion of repolarization, this was not observed in endocardial stimulation (van Deursen et al., 2009).

However, Spragg et al. compared the hemodynamic effects of endocardial pacing at sites directly transmural to the CS lead tip in a small study of patients and found no difference in hemodynamics (Spragg et al., 2010). In this study a superior hemodynamic result was seen in 8 of 11 patients when endocardial pacing was performed from extreme basal sites at positions adjacent to the mitral ring. In a study by Derval et al. (Derval et al., 2010) pacing at the best LV site in 35 patients with non-ischemic dilated cardiomyopathy was associated with twice the improvement in $+\mathrm{dP} / \mathrm{dT}(\max )$ compared to CS pacing.

In summary, the major benefit of endocardial left ventricular pacing seems to be the access to all LV regions, whereas endocardial stimulation per se seems to be only of minor relevance.

In a few patients with major surgical contraindications to epicardial LV leads have been implanted through a transseptal approach (Jaïs et al., 2000; Leclercq et al., 1999; van Gelder et al., 2007). However, this approach is technically challenging. In addition to the risk of thromboembolism due to leads in the LV cavity, the adjacency to the mitral valve carries the risk of mitral insufficiency as well as endocarditis in case of infectious complications. A transapical approach which has been described by Kassai et al. in a limited number of patients would avoid passage of the mitral valve (Kassai et al., 2008).

\subsection{Magnetically navigated LV lead implantation}

A tortuous course of the coronary venous tree and target veins with small diameters can sometimes be challenging for CS lead implantation. New wire and lead navigation systems might facilitate lead implantation. The Niobe System (Stereotaxis Inc., St. Louis, USA) allows remote magnet controlled navigation of catheters and guidewires. The magnetically navigation system consists of two permanent magnets creating a steerable magnetic field (figure 3). The magnetic guidewires include a small magnet at their tip and can be steered by changing the orientation of the outer magnets. The magnetic field vector is displayed on a monitor and can be changed from the control room or from a bedside touch-screen monitor with sterile covers (figure 4).

We studied 123 patients who were assigned to either conventional CS lead implantation or LV lead implantation using magnetic navigation (Mischke et al., 2009). Venography of the coronary venous system was performed to select a target vessel for lead implantation. Left ventricular lead placement was analyzed with regard to three endpoints: 1) engagement of the target vessel with the guidewire, 2) over-the-wire lead placement in the target vessel, and 3) final LV lead position. Guidewire access to the target vessel was achieved in all patients using magnetic navigation compared to $87 \%$ with the conventional approach $(\mathrm{p}<0.05)$. Implantation success rates, total procedure and fluoroscopy times did not differ significantly between groups. Gallagher et al. used the Niobe system for CRT implantation in 50 patients (Gallagher et al., 2007). In this study, vessels were engaged either by CS venography and the use of a magnetic guidewire or via a "bare wire" approach without venography or special CS delivery sheaths. For the "bare wire" approach, the guidewire was used to probe for a target vessel as a substitute for CS venography. This was associated with a reduction in procedure and fluoroscopy time compared to the use of CS sheaths and venography. 


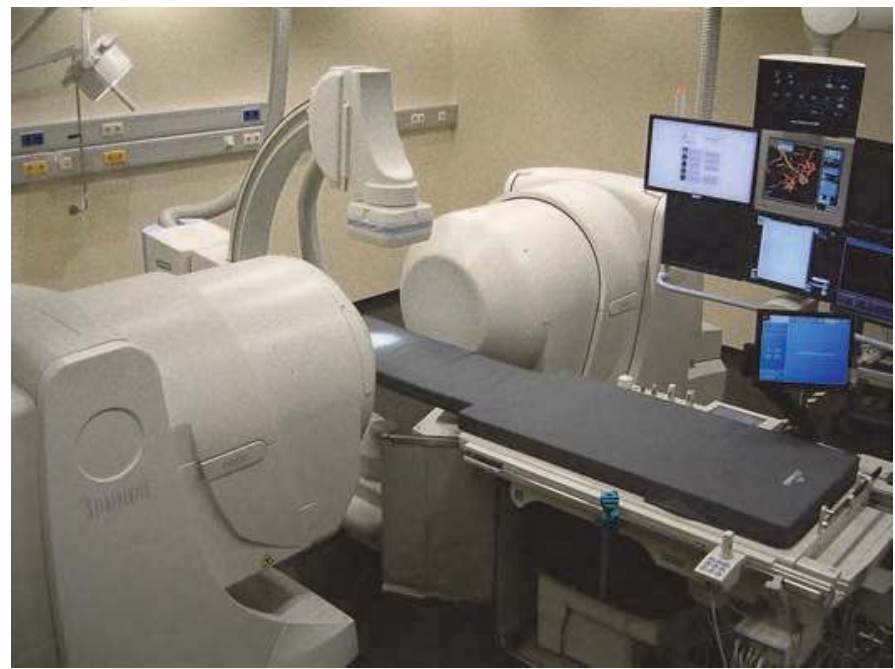

Fig. 3. Catheter suite with a magnetic navigation system (Niobe). Permanent magnets to both sides of the fluoroscopy table can be moved inside their casings to alter the magnetic field.

Magnetic navigation might be used as an additional tool for precise wire navigation and enable the operator to engage target vessels that are tortuous. In addition, technical advances in lead design might allow engagement of vessels which are now being considered inadequate due to morphology or size. We have recently demonstrated the feasibility of left ventricular stimulation via a miniaturized magnetized stimulation wire in an acute animal model (Knackstedt et al., 2010b). A conventional guide wire with a permanent magnet and a single stimulation electrode at its tip was coated with iridium oxide at the distal end and insulated except for the very tip. The stimulation wire was steered into side branches of the coronary sinus via magnetic navigation and successful left ventricular stimulation was performed via the wire.

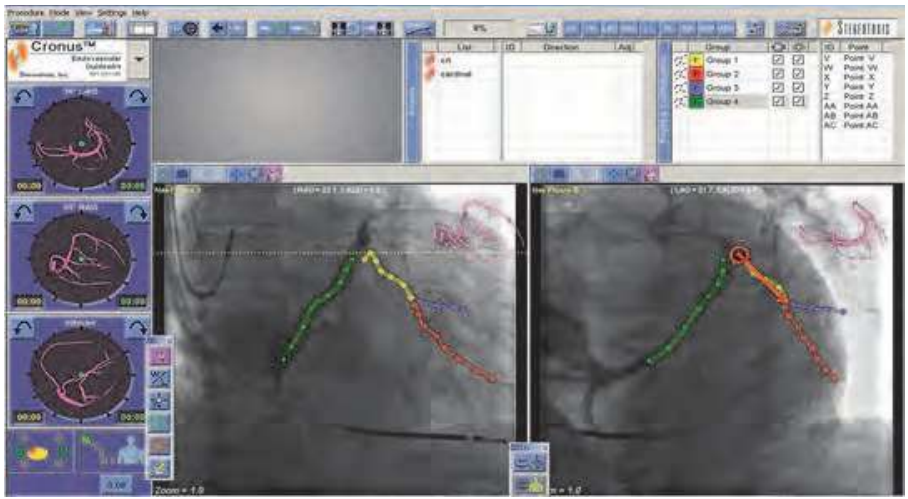

Fig. 4. Navigant screenshot. Two x-ray images have been transferred to the navigation software and tributaries of the CS have been marked with colors. The red arrow indicates the direction of the magnetic field vector. 


\subsection{Video-assisted pericardioscopic epicardial lead implantation}

In an animal study we used flexible and rigid endoscopy for implantation of epicardial pacing leads via a subxiphoidal access (Hatam et al., 2010). Rigid endoscopy showed to be superior to flexible endoscopy with regard to stability and orientation within the pericardial space, and leads were successfully implanted onto all four cardiac chambers. This minimally invasive procedure allows access to all left ventricular regions. However, this technique requires a subxiphoidal access to the epicardial space and the endoscopy is associated with ventricular arrhythmias.

\subsection{Leadless pacing}

Pacing without pacemaker leads would decrease the risk of infection and might allow multisite pacing and thus decrease dyssynchrony. Ultrasound and magnetic field waves have been used to induce electrical stimulation via an intracardiac receiver electrode (Kapa et al., 2010; Lee et al., 2007). In an animal study Echt et al. (Echt et al., 2006) used burst ultrasound energy transmission through the chest to a receiver electrode mounted on a catheter that converted the ultrasound energy to electrical energy sufficient to pace the myocardium. Biventricular pacing was also possible in this acute animal study. Microscopic evaluation revealed no evidence of mechanical or thermal bioeffects. Lee et al. successfully tested this system in patients undergoing electrophysiological studies (Lee et al., 2006). The technology in this study is under development as a leadless implantable system for chronic use. Technical challenges include a high beat-to-beat variation in the receiver electrode output as well as inefficient energy conversion: less than $1 \%$ of the transmitted energy was used for cardiac pacing.

In an acute animal study Wieneke (Wieneke et al., 2009) demonstrated the feasibility of cardiac pacing via induction technology. The systems consisted of a transcutaneously implanted transmitter unit made of a ring-shaped copper coil and a receiver unit implanted in the right ventricular apex. The transmitter generated an alternating magnetic field of around $0.5 \mathrm{mT}$ that was converted into a voltage pulse by the receiver in order to pace the ventricle. So far results have been published from one pig only, and no data on chronic pacing are availably.

A promising miniaturized leadless pacemaker is being developed by Medtronic (Minneapolis, USA): the small device can be deployed with a catheter from a venous access and implanted into the ventricular cavity. Up to now no animal or human data have been published about the device.

\section{Electrical remodeling in CRT}

In congestive heart failure (CHF), a complete left bundle branch block causes asynchronous ventricular contraction due to regional dispersion of ventricular depolarization, resulting in intra- and interventricular mechanical asynchrony. CRT reduces the heterogeneity of ventricular contraction by biventricular stimulation.

Especially patients with a very broad QRS-complex (> $150 \mathrm{msec}$ ) seem to profit most from CRT (Chung et al., 2008; Moss et al., 2009). Although QRS duration is not an optimal criterion for selecting patients amenable for CRT and some studies have failed to predict clinical and echocardiographic response to CRT, it remains an important criterion for dyssynchrony for the indication of CRT (Boriani et al., 2006; Gervais et al., 2009; Hawkins et al., 2006; Mollema et al., 2007). 
In CRT, biventricular stimulation usually results in a narrowing of the stimulated QRScomplex and a reduction in left ventricular chamber size as well as improvement in ejection fraction. The extent of the QRS shortening induced by biventricular pacing seems to correlate with the structural remodeling (Boriani et al., 2006; Kronborg et al., 2010). However, about one third of patients fail to respond to CRT (Cleland et al., 2001; Chung et al., 2008; Lafitte et al., 2009). A lot of effort has been spent to both identify patients who are likely to benefit from CRT and to increase the benefit from CRT, e.g. by optimizing AV and VV delays (Strauss et al., 2010).

Although CRT has been shown to induce a structural remodeling resulting in reduction in left ventricular dimensions and improvement in ejection fraction, there is scarce and controversial data on a possible remodeling of the native conduction system (Dizon et al., 2004; Henrikson et al., 2007; Stockburger et al., 2008).

We studied the effect of CRT on the native conduction system in a small prospective study (Mischke et al., 2011). A CRT device was implanted in 38 patients with congestive heart failure (ejection fraction (EF): $26 \pm 7 \%$ ). 20 patients suffered from dilated cardiomyopathy and 18 from ischemic cardiomyopathy. Standard 12-lead ECGs with and without pacing as well as echocardiographies were obtained prior to implantation and after 6 and 12 months. Patients were classified as responders in case of an increase in $\mathrm{EF} \geq 25 \%$ in combination with an increase in NYHA class $\geq 1$. The EF increased to $36 \pm 10 \%(\mathrm{p}<0.0001)$ after 6 months and $40 \pm 12 \%(\mathrm{p}<0.0001)$ after 12 months of CRT. Intrinsic QRS duration decreased from $171 \pm 18$ $\mathrm{ms}$ before CRT to $164 \pm 23 \mathrm{~ms}(\mathrm{p}=0.027)$ after 6 months and $161 \pm 25 \mathrm{~ms}(\mathrm{p}=0.002)$ after 12 months of CRT (figure 5). 22 patients (58\%) were classified as responders. Whereas a significant decrease in intrinsic QRS duration was observed in responders, only a slight decrease was seen in non-responders. However, two-factorial variance analyses did not show a significant influence of response or underlying heart disease (dilated or ischemic cardiomyopathy) on the change in QRS duration ( $p=0.7)$.

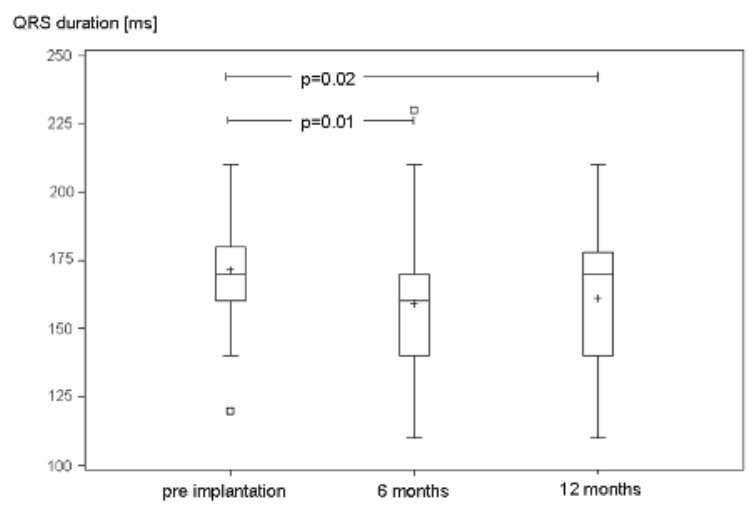

Fig. 5. Baseline and intrinsic QRS duration (from Mischke et al., 2011)

This was the first prospective study to demonstrate a decrease in intrinsic QRS duration in patients treated with CRT. Dizon et al. reported the first case of loss of bundle branch block in a patient 6 months after implantation of a CRT device (Dizon et al., 2004). However, data on intrinsic QRS duration is controversial. No change in intrinsic QRS duration was seen in 
the MUSTIC trial as well as in a study by Stockburger (Stockburger et al., 2008). Two studies displayed a trend towards a reduction in intrinsic QRS duration (Boriani et al., 2006; Vogt et al., 2000). Similar to our results, a retrospective study by Henrikson et al. showed a significant reduction in intrinsic QRS duration after 14 months of CRT in 25 patients (Henrikson et al., 2007). Experimental data suggest a subcellular redistribution of connexin43 and ion channel remodeling with a reduction in inward rectifier $\mathrm{K}+$ current, delayed rectifier $\mathrm{K}^{+}$current and transient outward $\mathrm{K}^{+}$current) and abnormal $\mathrm{Ca}^{2+}$ homeostasis in left bundle branch block (Aiba et al., 2009; Spragg et al., 2005). CRT partially restored this ion channel remodeling and attenuated the regional heterogeneity of action potential duration. Although human data on intrinsic QRS duration in CRT is controversial, an impact on the conduction system by several factors including connexin redistribution and reduction in left ventricular dimensions is quite conceivable.

\section{Conclusion}

Cardiac resynchronization therapy is an effective treatment for patients with congestive heart failure and complete left bundle branch block. However, about one third of all patients who undergo CRT do not profit from it. Several strategies have been tried to reduce the percentage of non-responders, including optimized patient selection, device programming and optimized positioning of the left ventricular lead. However, due to high interpatient variability there seems to be no single best pacing site for all patients. Acute hemodynamic testing during implantation is time-consuming and good acute effects might not translate into a long-term clinical benefit.

None of these approaches has had a relevant impact on daily practice yet. In order to have the maximum benefit for our patients, we need to individualize the approach to CRT. Technical advances, like new lead designs and guiding catheters, are crucial for the further progress in CRT.

\section{References}

Abraham WT, Fisher WG, Smith AL, Delurgio DB, Leon AR, Loh E, Kocovic DZ, Packer M, Clavell AL, Hayes DL, Ellestad M, Trupp RJ, Underwood J, Pickering F, Truex C, McAtee P, Messenger J; MIRACLE Study Group. Multicenter InSync Randomized Clinical Evaluation. (2002). Cardiac resynchronization in chronic heart failure. $N$ Engl J Med, Vol. 346, pp. 1845-1853.

Al-Khadra AS. (2005). Use of preshaped sheath to plan and facilitate cannulation of the coronary sinus for the implantation of cardiac resynchronization therapy devices: preshaped sheath for implantation of biventricular devices. Pacing Clin Electrophysiol, Vol. 28, pp. 489-492.

Aiba T, Hesketh GG, Barth AS Liu T, Daya S, Chakir K, Dimaano VL, Abraham TP, O'Rourke B, Akar FG, Kass DA, Tomaselli GF. (2009). Electrophysiological consequences of dyssynchronous heart failure and its restoration by resynchronization therapy. Circulation, Vol. 119, pp. 1220-1230

Becker M, Altiok E, Ocklenburg C, Krings R, Adams D, Lysansky M, Vogel B, Schauerte P, Knackstedt C, Hoffmann R. (2010). Analysis of LV lead position in cardiac resynchronization therapy using different imaging modalities. JACC Cardiovasc Imaging, Vol. 3, pp. 472-81 
Becker M, Kramann R, Franke A, Breithardt OA, Heussen N, Knackstedt C, Stellbrink C, Schauerte P, Kelm M, Hoffmann R. (2007a). Impact of left ventricular lead position in cardiac resynchronization therapy on left ventricular remodelling. A circumferential strain analysis based on 2D echocardiography. Eur Heart J, Vol. 28, pp. 1211-20.

Becker M, Franke A, Breithardt OE, Kaminski T, Kramann R, Knackstedt C, Stellbrink C, Hanrath P, Schauerte P, Hoffmann R. (2007b). Impact of Left Ventricular Lead Position on the Efficacy of Cardiac Resynchronization Therapy. A TwoDimensional Strain Echocardiography Study. Heart, Vol. 93, pp. 1197-203.

Bleeker GB, Kaandorp TA, Lamb HJ, Boersma E, Steendijk P, de Roos A, van der Wall EE, Schalij MJ, Bax JJ. (2006). Effect of posterolateral scar tissue on clinical and echocardiographic improvement after cardiac resynchronization therapy. Circulation, Vol. 113, pp. 969-76.

Boriani G, Biffi M, Martignani C, Ziacchi M, Saporito D, Grigioni F, Domenichini G, Valzania C, Diemberger I, Bertini M, Specchia S, Branzi A. (2006). Electrocardiographic remodeling during cardiac resynchronization therapy. Int $J$ Cardiol, Vol. 108, pp. 165-170.

Butter C, Auricchio A, Stellbrink C, Fleck E, Ding J, Yu Y, Huvelle E, Spinelli J; Pacing Therapy for Chronic Heart Failure II Study Group. (2001). Effect of resynchronization therapy stimulation site on the systolic function of heart failure patients. Circulation, Vol. 104, No. 25, pp. 3026-9.

Chung ES, Leon AR, Tavazzi LJ, Sun JP, Nihoyannopoulos P, Merlino J, Abraham WT, Ghio S, Leclercq C, Bax JJ, Yu CM, Gorcsan J 3rd, St John Sutton M, De Sutter J, Murillo J. (2008). Results of the predictors of response to CRT (PROSPECT) trial. Circulation Vol. 117, pp. 2608-2616.

Cleland JG, Daubert JC, Erdmann E, Freemantle N, Gras D, Kappenberger L, Tavazzi L; Cardiac Resynchronization-Heart Failure (CARE-HF) Study Investigators. (2005). The effect of cardiac resynchronization on morbidity and mortality in heart failure. N Engl J Med, Vol. 352, pp. 1539-1549.

de Cock CC, Giudici MC, Twisk JW. (2003). Comparison of the haemodynamic effects of right ventricular outflow-tract pacing with right ventricular apex pacing: a quantitative review. Europace, Vol. 5, No. 3:275-8.

Derval N, Steendijk P, Gula LJ, Deplagne A, Laborderie J, Sacher F, Knecht S, Wright M, Nault I, Ploux S, Ritter P, Bordachar P, Lafitte S, Réant P, Klein GJ, Narayan SM, Garrigue S, Hocini M, Haissaguerre M, Clementy J, Jaïs P. (2010). Optimizing hemodynamics in heart failure patients by systematic screening of left ventricular pacing sites: the lateral left ventricular wall and the coronary sinus are rarely the best sites. J Am Coll Cardiol, Vol. 55, pp. $566-75$.

Dizon J, Horn E, Neglia J Medina N, Garan H (2004) Loss of Left Bundle Branch Block following Biventricular Pacing Therapy for Heart Failure: Evidence for Electrical remodeling? JICE, Vol. 10, pp. 47-50.

Duckett SG, Ginks MR, Knowles BR, Ma Y, Shetty A, Bostock J, Cooklin M, Gill JS, CarrWhite GS, Razavi R, Schaeffter T, Rhode KS, Rinaldi CA. (2010) Advanced Image Fusion to Overlay Coronary Sinus Anatomy with Real-Time Fluoroscopy to Facilitate Left Ventricular Lead Implantation in CRT. Pacing Clin Electrophysiol doi: 10.1111/j.1540-8159.2010.02940.x. [Epub ahead of print] 
Echt DS, Cowan MW, Riley RE, Brisken AF. (2006). Feasibility and safety of a novel technology for pacing without leads. Heart Rhythm, Vol. 3, No. 10 pp.1202-6

Hatam N, Amerini AL, Steiner F, Lazeroms M, Mischke K, Schauerte P, Autschbach R, Spillner J. (2010). Video-assisted pericardioscopic surgery: refinement of a new technique for implanting epimyocardial pacemaker leads. Eur J Cardiothorac Surg [Epub ahead of print]

Henz BD, Friedman PA, Bruce CJ, Okumura Y, Johnson SB, Danielsen A, Packer DL, Asirvatham SJ. (2009). Synchronous ventricular pacing without crossing the tricuspid valve or entering the coronary sinus--preliminary results. J Cardiovasc Electrophysiol, Vol. 20, No. 12, pp.1391-7.

Gallagher P, Martin L, Angel L, Tomassoni G. (2007). Initial clinical experience with cardiac resynchronization therapy utilizing a magnetic navigation system. J Cardiovasc Electrophysiol, Vol. 18, pp.174-180.

Helm RH, Byrne M, Helm PA, Daya SK, Osman NF, Tunin R, Halperin HR, Berger RD, Kass DA, Lardo AC. (2007). Three-dimensional mapping of optimal left ventricular pacing site for cardiac resynchronization. Circulation, Vol. 115, pp. 95361

Henrikson CA, Spragg DD, Cheng A, Capps M, Devaughn K, Marine JE, Calkins H, Tomaselli GF, Berger RD. (2007). Evidence for electrical Remodeling of the Native Conduction System with Cardiac Resynchronization Therapy. Pacing Clin Electrophysiol Vol. 30, pp. 591-595.

Jaïs P, Takahashi A, Garrigue S, Yamane T, Hocini M, Shah DC, Barold SS, Deisenhofer I, Haïssaguerre M, Clémenty J. (2000). Mid-term follow-up of endocardial biventricular pacing. Pacing Clin Electrophysiol, Vol. 23, pp. 1744-7.

Kapa S, Bruce CJ, Friedman PA, Asirvatham SJ. (2010). Advances in cardiac pacing: beyond the transvenous right ventricular apical lead. Cardiovasc Ther, Vol. 28, No. 6, pp. 369-79.

Kassai I, Foldesi C, Szekely A, Szili-Torok T. (2008). New method for cardiac resynchronization therapy: transapical endocardial lead implantation for left ventricular free wall pacing. Europace, Vol. 10, No. 7, pp. 882-3.

Knackstedt C, Mühlenbruch G, Mischke K, Bruners P, Schimpf T, Frechen D, Schummers G, Mahnken AH, Günther RW, Kelm M, Schauerte P. (2008a). Imaging of the Coronary Venous System: Validation of Three-Dimensional Rotational Venous Angiography Against Dual-Source Computed Tomography. Cardiovasc Intervent Radiol,Vol. 31, No. 6, pp. 1150-8

Knackstedt C, Mühlenbruch G, Mischke K, Schimpf T, Spüntrup E, Günther RW, Sanli B, Kelm M, Schauerte P, Mahnken AH. (2008b). Imaging of the coronary venous system in patients with congestive heart failure: comparison of 16 slice MSCT and retrograde coronary sinus venography: Comparative imaging of coronary venous system. Int J Cardiovasc Imaging, Vol. 24, No. 8, pp. 783-91

Knackstedt C, Mühlenbruch G, Mischke K, Schummers G, Becker M, Kühl H, Franke A, Schmid M, Spuentrup E, Mahnken A, Lang RM, Kelm M, Günther R, Schauerte P. (2010a). Registration of Coronary Venous Anatomy the Site of Latest Mechanical Contraction. Acta Cardiol, Vol. 65, pp. 161-70

Knackstedt C, Schimpf T, Napp A, Wessling B, Rothe C, Mischke K, Schnakenberg U, Schauerte P. (2010b). Super-Selective Electrical Stimulation of the Left Ventricle via 
a Miniaturized Magnetized Stimulation Wire -Proof of Concept Study-. Biomed Tech (Berl), Vol. 55, pp.285-90.

Kronborg, MB, Nielsen JC, Mortensen PT. (2010). Electrocardiographic patterns and longterm clinical outcome in cardiac resynchronization therapy. Europace, Vol. 12, pp. 216-222.

Kypta A, Steinwender C, Kammler J, Leisch F, Hofmann R. (2008). Long-term outcomes in patients with atrioventricular block undergoing septal ventricular lead implantation compared with standard apical pacing. Europace, Vol. 10, No. 5, pp. 574-9.

Lafitte S, Reant P, Zaroui A, Donal E, Mignot A, Bougted H, Belghiti H, Bordachar P, Deplagne A, Chabaneix J, Franceschi F, Deharo JC, Dos Santos P, Clementy J, Roudaut R, Leclercq C, Habib G. (2009). Validation of an echocardiographic multiparametric strategy to increase responders patients after cardiac resynchronization: a multicentre study. Eur Heart J, Vol. 30, pp. 2880-2887.

Leclercq F, Hager FX, Macia JC, Mariottini CJ, Pasquié JL, Grolleau R. (1999). Left ventricular lead insertion using a modified transseptal catheterization technique: a totally endocardial approach for permanent biventricular pacing in end-stage heart failure. Pacing Clin Electrophysiol, Vol. 22, pp. 1570 -5.

Lee KL, Lau CP, Tse HF, Echt DS, Heaven D, Smith W, Hood M. (2007). First human demonstration of cardiac stimulation with transcutaneous ultrasound energy delivery: implications for wireless pacing with implantable devices. J Am Coll Cardiol, Vol. 50, No. 9, pp. 877-83

Ma H, Tang Q, Yang Q, Bi X, Lu H, Ge L, Lin K, Xu D, Du X, Lu J, An J, Jin L, Jerecic R. Li K, Li D. (2010). Contrast-enhance whole heart coronary MRA at 3.0T for the evaluation of cardiac venous anatomy. In J Cardiovasc Imaging, in press

Mischke K, Knackstedt C, Fache K, Reith S, Rana O, Saygili E, Gemein C, Becker M, Marx N, Schauerte P. (2011). Electrical remodelling in cardiac resynchronization therapy: decrease in intrinsic QRS duration. Acta Cardiol, in press

Mischke K, Knackstedt C, Schmid M, Hatam N, Becker M, Spillner J, Fache K, Kelm M, Schauerte P. (2009). Initial experience with remote magnetic navigation for left ventricular lead placement. Acta Cardiol, Vol. 64, No. 4, pp. 467-475

Mischke K, Knackstedt C, Mühlenbruch G, Schimpf T, Neef N, Zarse M, Plisiene J, Stanzel S, Eickholt C, Spüntrup E, Frechen D, Hanrath P, Kelm M, Schauerte P. (2007). Imaging of the coronary venous system: retrograde coronary sinus angiography versus venous phase coronary angiograms. Int J Cardiol, Vol. 119, No. 3, pp.339-43

Moss AJ, Hall WJ, Cannom DS, Klein H, Brown MW, Daubert JP, Estes NA 3rd, Foster E, Greenberg H, Higgins SL, Pfeffer MA, Solomon SD, Wilber D, Zareba W; MADITCRT Trial Investigators. (2009). Cardiac-resynchronization therapy for the prevention of heart-failure events. N Engl J Med, Vol.. 361, pp.1329-1338.

Nezafat R, Han Y, Peters DC, Herzka DA, Wylie JV, Goddu B, Kissinger KK, Yeon SB, Zimetbaum PJ, Manning WJ. (2007). Coronary magnetic resonance vein imaging: imaging contrast, sequence, and timing. Magn Reson Med, Vol. 58, pp. 1196-206

Purerfellner H, Nesser HJ, Winter S, Schwierz T, Hornell H, Maertens S. (2000). Transvenous left ventricular lead implantation with the EASYTRAK lead system: the European experience. Am J Cardiol, Vol. 86, pp. 157K-164K. 
Spragg DD, Akar FG, Helm RH, Tunin RS, Tomaselli GF, Kass DA. (2005). Abnormal conduction and repolarization in late-activated myocardium of dyssynchronously contracting hearts. Cardiovasc Res, Vol. 67, pp. 77-86.

Spragg DD, Dong J, Fetics BJ, Helm R, Marine JE, Cheng A, Henrikson CA, Kass DA, Berger RD. (2010). Optimal left ventricular endocardial pacing sites for cardiac resynchronization therapy in patients with ischemic cardiomyopathy. J Am Coll Cardiol,Vol. 56, No. 10, pp. 774-81.

Stockburger M, Nitardy A, Fateh-Moghadam S, Krebs A, Celebi O, Karhausen T, Dietz R. (2008). Electrical remodeling and cardiac dimensions in patients treated by cardiac resynchronization and heart failure controls. Pacing Clin Electrophysiol, Vol. 31, pp. 70-77.

Strauss M, Becker T, Kleemann T, Dyck N, Birkenhauer F, Seidl K. (2010). Impact of moderate exercise workload on predicted optimal AV and VV delays determined by an intracardiac electrogram-based method for optimizing cardiac resynchronization therapy. Clin Res Cardiol, Vol. 99, pp. 735-41.

Tantengco MV, Thomas RL, Karpawich PP. (2001) Left ventricular dysfunction after longterm right ventricular apical pacing in the young. J Am Coll Cardiol, Vol. 37, No. 8, pp. 2093-100.

Tops LF, Schalij MJ, Bax JJ. (2009). The effects of right ventricular apical pacing on ventricular function and dyssynchrony implications for therapy. J Am Coll Cardiol, Vol. 54, No. 9, pp. 764-76.

Van de Verie NR, Schuij JD, De Sutter J, Devos D, Bleeker GB, de Roos A, van der Wall ÄEE, Schalij MG, Bax JJ. (2006). Non-invasive visualization of the cardiac venous system in coronary artery disease patients using 64-slice computed tomography. J Am Coll Cardiol, Vol. 48, pp. 1832-8.

van Deursen C, van Geldorp IE, Rademakers LM, van Hunnik A, Kuiper M, Klersy C, Auricchio A, Prinzen FW. (2009). Left ventricular endocardial pacing improves resynchronization therapy in canine left bundle-branch hearts. Circ Arrhythm Electrophysiol, Vol. 2, pp. $580-7$.

Vanerio G, Vidal JL, Fernández Banizi P, Banina Aguerre D, Viana P, Tejada J. (2008). Medium- and long-term survival after pacemaker implant: Improved survival with right ventricular outflow tract pacing. J Interv Card Electrophysiol, Vol. 21, No. 3, pp.195-201.

van Gelder BM, Scheffer MG, Meijer A, Bracke FA. (2007). Transseptal endocardial left ventricular pacing: an alternative technique for coronary sinus lead placement in cardiac resynchronization therapy. Heart Rhythm, Vol. Vol. 4, pp. 454-60.

van Gelder BM, Bracke FA, Oto A, Yildirir A, Haas PC, Seger JJ, Stainback RF, Botman KJ, Meijer A. (2000). Diagnosis and management of inadvertently placed pacing and ICD leads in the left ventricle: a multicenter experience and review of the literature. Pacing Clin Electrophysiol, Vol. 23, No. 5, pp. 877-83.

Vogt J, Krahnefeld O, Lamp B, Hansky B, Kirkels H, Minami K, Körfer R, Horstkotte D, Kloss M, Auricchio A. (2000). Pacing Therapies in Congestive Heart Failure Study Group. Electrocardiographic remodeling in patients paced for heart failure. Am J Cardiol, Vol. 86, pp. 152K-156K.

Wieneke H, Konorza T, Erbel R, Kisker E. (2009). Leadless pacing of the heart using induction technology: a feasibility study. Pacing Clin Electrophysiol, Vol. 32, No. 2, pp. 177-83. 
White JA, Yee R, Yuan X, Krahn A, Skanes A, Parker M, Klein G, Drangova M. (2006). Delayed enhancement magnetic resonance imaging predicts response to cardiac resynchronization therapy in patients with intraventricular dyssynchrony. J Am Coll Cardiol, Vol. 48, pp. 1953-60.

Ypenburg C, van Bommel RJ, Delgado V, Mollema SA, Bleeker GB, Boersma E, Schalij MJ, Bax JJ. (2008). Optimal left ventricular lead position predicts reverse remodeling and survival after cardiac resynchronization therapy. J Am Coll Cardiol, Vol. 52, pp. 1402-9.

Yu CC, Liu YB, Lin MS, Wang JY, Lin JL, Lin LC. (2007). Septal pacing preserving better left ventricular mechanical performance and contractile synchronism than apical pacing in patients implanted with an atrioventricular sequential dual chamber pacemaker. Int J Cardiol, Vol. 118, No. 1, pp. 97-106. 


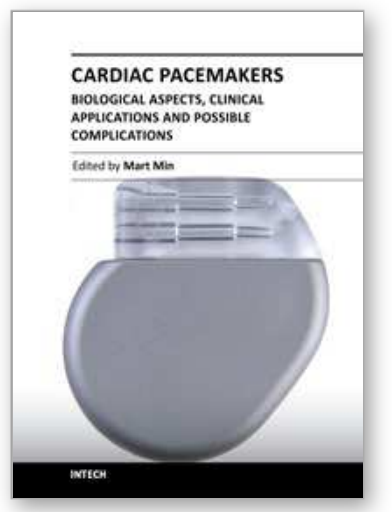

\section{Cardiac Pacemakers - Biological Aspects, Clinical Applications and Possible Complications}

Edited by Prof. Mart Min

ISBN 978-953-307-639-3

Hard cover, 194 pages

Publisher InTech

Published online 06, September, 2011

Published in print edition September, 2011

Clinical usage of artificial pacing dates back to 1958, when the battery powered cardiac pacemakers became available. Modern implantable pacemakers are the complicated electronic devices operating 10 years continuously without battery exchange. Though the development of devices is not a primary topic of the book, certain efforts towards developing of biologic pacemakers through tissue engineering and studying of cell synchronization are discussed. The main attention is paid to implementations of pacemakers in different medical situations oriented towards widening the clinical indications for implanting the cardiac pacemakers. New methods and devices in cardiac resynchronization therapy (CRT) have received particular attention. Placing of pacing electrodes has been treated soundly. Furthermore, emerging of complexities and complications in new clinical situations and other safety problems have been discussed thoroughly. The authors have derived the used information from their own clinical practice and experiences of their medical colleagues. These and other pragmatic features can be acknowledged as the most valuable asset of the book.

\section{How to reference}

In order to correctly reference this scholarly work, feel free to copy and paste the following:

Karl Mischke and Christian Knackstedt (2011). Cardiac Resynchronization Therapy: Lead Positioning and Technical Advances, Cardiac Pacemakers - Biological Aspects, Clinical Applications and Possible Complications, Prof. Mart Min (Ed.), ISBN: 978-953-307-639-3, InTech, Available from: http://www.intechopen.com/books/cardiac-pacemakers-biological-aspects-clinical-applications-and-possiblecomplications/cardiac-resynchronization-therapy-lead-positioning-and-technical-advances 1

\section{INTECH}

open science | open minds

\section{InTech Europe}

University Campus STeP Ri Slavka Krautzeka 83/A

51000 Rijeka, Croatia

Phone: +385 (51) 770447

Fax: +385 (51) 686166

www.intechopen.com

\section{InTech China}

Unit 405, Office Block, Hotel Equatorial Shanghai

No.65, Yan An Road (West), Shanghai, 200040, China 中国上海市延安西路65号上海国际贵都大饭店办公楼 405 单元

Phone: +86-21-62489820

Fax: $+86-21-62489821$ 
(C) 2011 The Author(s). Licensee IntechOpen. This chapter is distributed under the terms of the Creative Commons Attribution-NonCommercialShareAlike-3.0 License, which permits use, distribution and reproduction for non-commercial purposes, provided the original is properly cited and derivative works building on this content are distributed under the same license. 